\title{
Effect of two digestive enzymes and pH on the dsRNA of endornaviruses of bell pepper and melon under in vitro conditions
}

\author{
Adair McCanless ${ }^{1} \cdot$ Allison Hultgren $^{1} \cdot$ Cesar Escalante $^{1} \cdot$ Alyssa Ardt $^{1} \cdot$ Rodrigo A. Valverde $^{1}$ (D)
}

Received: 18 June 2019 / Accepted: 3 November 2019/Published online: 15 November 2019

(C) The Author(s) 2019

\begin{abstract}
Purpose The objective of this investigation was to determine the in vitro effect of two common digestive enzymes, amylase and pepsin, and $\mathrm{pH}$ on the integrity of the RI dsRNA of bell pepper endornavirus (BPEV) and Cucumis melo endornavirus (CmEV) evaluated by gel electrophoresis and reverse-transcription PCR (RT-PCR).

Methods We conducted experiments on the in vitro effect of two common digestive enzymes, amylase and pepsin, and $\mathrm{pH}$ on the structural integrity of the replicative intermediate (RI) dsRNA of bell pepper endornavirus (BPEV) and Cucumis melo endornavirus $(\mathrm{CmEV})$, evaluated by gel electrophoresis and reverse-transcription polymerase chain reaction.

Result The effect of the amylase, pepsin, and $\mathrm{pH}$ treatments on the dsRNA of both viruses was similar. Amylase did not appear to affect the structural integrity of the dsRNA. In contrast, gel electrophoresis analysis of pepsin-treated dsRNA samples showed an abnormal electrophoretic migration and evidence of partial dsRNA degradation. DsRNAs from both fruits were partially degraded when exposed to a $\mathrm{pH}$ value of 2.0 and completely degraded at a $\mathrm{pH}$ value of 1.0.

Conclusion The results of this investigation suggest that when exposed to pepsin and $\mathrm{pH}$ values lower than 2.0, the RI of BPEV and $\mathrm{CmEV}$ lose their structural integrity. Therefore, when consuming endornavirus-infected bell pepper or melon, our digestive organs are exposed to both fragmented and full RI dsRNA of these two viruses.
\end{abstract}

Keywords Amylase - Capsicum annuum - Cucumis melo · Plant virus · Pepsin · Pepper mild mottle virus · Replicative intermediate dsRNA

\section{Findings}

Plant viruses have been shown to be present in fruits, roots, leaves, seeds, and some processed plant products commonly available in grocery stores (Pavan et al. 2008; Willenborg et al. 2009; Colson et al. 2010; Okada et al. 2011; Sabanadzovic et al. 2016; Szostek et al. 2017). Some of these viruses, such as cowpea mosaic virus (CPMV) and pepper mild mottle virus (PMMoV), have been shown to be stable and infectious under simulated gastric conditions (Zhang et al. 2006; Berardi et al. 2018). Several studies have shown that plant viruses are

Electronic supplementary material The online version of this article (https://doi.org/10.1007/s13213-019-01530-2) contains supplementary material, which is available to authorized users.

Rodrigo A. Valverde

rvalverde@agcenter.lsu.edu

1 Department of Plant Pathology and Crop Physiology, Louisiana State University Agricultural Center, Baton Rouge, LA 70803, USA common in human feces and, in some cases, their infectivity has been confirmed and their genome assembled (Zhang et al. 2006; Colson et al. 2010; da Costa et al. 2019). The presence of these viruses is likely the result of consumption of virusinfected plant products (Colson et al. 2010; da Costa et al. 2019).

In plant virology, the terms acute and persistent have been used to describe symptomatic and asymptomatic reactions of plants to viruses (Roossinck 2010). Most acute plant viruses can render the host unfit for certain environments. In contrast, persistent plant viruses do not appear to affect the phenotype of the host (Boccardo et al. 1987; Roossinck 2010; Fukuhara 2019). The virus family Endornaviridae includes viruses that infect fungi, oomycetes, and plants (Fukuhara 2019; Valverde et al. 2019). In plants, endornaviruses are persistent viruses which have not been shown to cause diseases (Fukuhara 2019). The genome of plant endornaviruses consist of linear ssRNA ranging in size from approximately $13-18 \mathrm{~kb}$, lacking capsid protein and cell-to-cell movement, and indirect evidence suggests that they are present in all tissues of the 
infected plant (Fukuhara 2019; Valverde et al. 2019). Endornaviruses have been reported to infect economically important agronomic crops such as barley, common bean, and rice (Wakarchuk and Hamilton 1985; Zabalgogeazcoa and Gildow 1992; Fukuhara et al. 1993). Pepper (Capsicum annuum), an important vegetable crop, has been shown to be infected with bell pepper endornavirus (BPEV), a virus with a genome of about $14.7 \mathrm{~kb}$ in length (Okada et al. 2011). In the USA, all tested commercial cultivars of bell pepper have been found to be infected with BPEV (Okada et al. 2011). Melon (Cucumis melo), another food crop cultivated for fresh fruit consumption and nutritional value, has been reported infected with Cucumis melo endornavirus $(\mathrm{CmEV})$ which has a genome of about $15 \mathrm{~kb}$ (Sabanadzovic et al. 2016). As in the case of bell pepper, all melon commercial cultivars tested in the USA were infected with CmEV (Sabanadzovic et al. 2016). The replicative intermediate (RI) double-stranded RNAs (dsRNAs) of these endornaviruses can be readily and consistently extracted from infected plants (Okada et al. 2011; Sabanadzovic et al. 2016; Khankhum et al. 2017).

The objective of this investigation was to determine the in vitro effect of two common digestive enzymes, amylase and pepsin, and $\mathrm{pH}$ on the integrity of the RI dsRNA of BPEV and CmEV evaluated by gel electrophoresis and reverse-transcription PCR (RT-PCR).

Seeds of BPEV-infected bell pepper cv. Marengo and seeds of CmEV-infected melon cv. PMR-45 were planted and the plants were grown to maturity in a greenhouse. Fruits were collected and tested for endornavirus by dsRNA extraction, gel electrophoresis, and RT-PCR as described below and infected tissues were used in all the experiments. Fruits from a BPEV-free line of bell pepper cv. Marengo generated in previous research were used as the source of BPEV-free fruit tissue (Okada et al. 2011). Approximately $2.0 \mathrm{~g}$ of fresh tissue from endornavirus-infected bell pepper and melon fruits was dissected with a scalpel and macerated into a paste with a mortar and pestle in $1.0 \mathrm{~mL}$ of tris buffer $(0.1 \mathrm{M} \mathrm{NaCl}$, $0.05 \mathrm{M}$ tris, $0.001 \mathrm{M}$ EDTA, $\mathrm{pH}$ 6.8). Two grams of tissue from BPEV-free bell pepper fruits were also macerated. Five hundred milligrams of the tissue macerate was placed in a 2.0 $\mathrm{mL}$ microcentrifuge tube, and the appropriate enzyme treatment was applied. To test the effect of $\mathrm{pH}$, approximately $10 \mathrm{~g}$ of tissue was dissected from the fruits and macerated in 5.0 $\mathrm{mL}$ tris buffer. The macerated tissue was placed in a beaker, $\mathrm{pH}$ adjusted with $1.0 \mathrm{M} \mathrm{HCl}$ to the appropriate value, and $0.5 \mathrm{~g}$ of the macerate placed in $2.0-\mathrm{mL}$ tubes. Negative controls consisted of tris buffer-treated tissue macerates. The amounts of amylase and pepsin, used to treat tissue macerates, were based on reports of common concentrations of these enzymes in humans (Kalipatnapu et al. 1983; Roberts et al. 2007; Mandel et al. 2010; Foltz et al. 2015; Liu et al. 2015). Similarly, the range of $\mathrm{pH}$ values included $\mathrm{pH}$ values commonly detected in human gastric media (Zhu et al. 2006; Lu et al. 2010). All enzyme and $\mathrm{pH}$ treatments were conducted in duplicates and experiments were repeated at least twice. To each $0.5 \mathrm{~g}$ of macerated tissue, $\alpha$-amylase from human saliva type XIII-A (Sigma-Aldrich) $10 \mathrm{U} / \mu \mathrm{L}$ was added to adjust the amylase concentration in the macerate to $2.0,3.0$, and $4.0 \mathrm{mg} /$ $\mathrm{mL}$. The macerated tissue was vortexed at $1000 \mathrm{rpm}$ for $30 \mathrm{~s}$ at room temperature, and dsRNA was extracted. Pepsin from porcine gastric mucosa $(250 \mathrm{U} / \mathrm{mg})$ (Sigma-Aldrich) was added to each $0.5 \mathrm{~g}$ of macerated tissue to final concentrations of $0.5,0.7$, and $1.0 \mathrm{mg} / \mathrm{mL}$. After vortexing at $1000 \mathrm{rpm}$ for 30 $\mathrm{s}$, the mixture was incubated in an Orbit Environ Shaker (Lab Line Instruments Inc., Melrose Park, IL, USA) at $37{ }^{\circ} \mathrm{C}$, $150 \mathrm{rpm}$ for $2 \mathrm{~h}$, and dsRNA was extracted. To determine if the 2-h incubation period had an effect on the dsRNA extraction, buffer-treated tissue macerates, subjected to the incubation conditions, were also extracted. Hydrochloric acid (1 M) was added to $0.5 \mathrm{~g}$ of macerated tissues to obtain the following $\mathrm{pH}$ values: 1.0, 2.0, 3.0, and 4.0. Samples were vortexed at $1000 \mathrm{rpm}$ for $30 \mathrm{~s}$ and incubated in an Orbit Environ Shaker (Lab Line Instruments) at $37^{\circ} \mathrm{C}, 150 \mathrm{rpm}$ for $2 \mathrm{~h}$, and dsRNA was extracted. To determine the effect of a combined treatment of amylase, pepsin, and $\mathrm{pH}$ to the endornavirus dsRNA, we conducted the treatments described above simultaneously on bell pepper and melon tissue macerates. Although, our primary objective was to test the dsRNA of two persistent viruses (BPEV and CmEV), we also conducted experiments with purified preparations of dsRNA from the acute virus PMMoV. Foliar tissue of an endornavirus-free line of bell pepper Marengo infected with a Louisiana isolate of PMMoV was used as the source of dsRNA (Escalante et al. 2018; Okada et al. 2011).

After the appropriate experimental treatment, dsRNA was extracted from the macerated fruit tissues as described by Khankhum et al. (2017). The extracted dsRNA was suspended in $35 \mu \mathrm{L}$ of water and treated with 1 unit of RNase-free DNase I (Sigma-Aldrich). After staining with $5 \mu \mathrm{L}$ of $100 \mathrm{X}$ GelRed ${ }^{\circledR}$ (Biotium, Hyward, CA, USA), 15-25 $\mu \mathrm{L}$ aliquots were loaded in $1.2 \%$ agarose gels prepared with $45 \mathrm{mM}$ Tris-borate 1 mM EDTA buffer. A 1-kb Molecular Ruler (Bio-Rad, Hercules, CA, USA) was included as marker. Gels were run for 1.5-2.0 h, and results were recorded with a GelDoc-It2 Imager (UVP, Upland, CA).

We also evaluated the effect of $\mathrm{pH}$, amylase, and pepsin on $40 \mu \mathrm{L}$ of purified BPEV (300-400 ng) and CmEV (200-300 ng) dsRNA extracted from $0.5 \mathrm{~g}$ of tissue macerate. The same enzyme concentrations, $\mathrm{pH}$, and incubation conditions used with the macerated tissue treatments were used to treat purified dsRNAs. After each treatment, the dsRNA was ethanol precipitated and resuspended in $35 \mu \mathrm{L}$ of tris buffer and 15-25 $\mu \mathrm{L}$ aliquots electrophoresed as described above. Negative controls consisted of tris buffer-treated dsRNA.

After the amylase, pepsin, and $\mathrm{pH}$ treatments of the fruit tissue samples, in addition to gel electrophoresis, the presence 
of BPEV and CmEV in the extracts was determined by RTPCR. Similarly, RT-PCR was performed on purified dsRNA after the treatments. Two sets of primers were used for each virus. For the detection of $\mathrm{CmEV}$, a pair of primers, Endor-F (5'AAGSGAGAATWATHGTRTGGCA 3') and Endor-R (5' CTAGWGCKGTBGTAGCTTGWCC 3') were used as described by Valverde et al. (2011). For the detection of BPEV, we designed a pair of primers (BPE-3F: 5'- CCAGCCAA CAAACCAAATGT -3' and BPE-4R: 5'- CTGCCTAA TGATGGCTGTTG $-3^{\prime}$ ) which amplify $572 \mathrm{nT}$ of the UDPglycosyltransferase of BPEV. After initial denaturation at 94 ${ }^{\circ} \mathrm{C}$ for $1 \mathrm{~min}$, the cDNAs were amplified by 40 cycles as follows: denaturation $1 \mathrm{~min}$ at $94{ }^{\circ} \mathrm{C}$, annealing $1 \mathrm{~min}$ at 58 ${ }^{\circ} \mathrm{C}$, extension for $2 \mathrm{~min}$ at $70{ }^{\circ} \mathrm{C}$, and a final extension for $7 \mathrm{~min}$ at $70^{\circ} \mathrm{C}$. For RT-PCR detection of PMMoV, we used virus-specific primers which amplified a 387-bp fragment of the viral coat protein and followed the procedure described by Jarret et al. (2008). RT-PCR products were analyzed by gel electrophoresis as described above. A 100-bp PCR Molecular Ruler (Bio-Rad) was included as marker.

In this investigation, we defined dsRNA structural integrity as the intactness or state of degradation of the dsRNA evaluated by gel electrophoresis. We used RT-PCR to confirm the identity of the viruses and detect low concentrations of viral RNA, which may not be detectable by gel electrophoresis.

The dsRNA of both endornaviruses was obtained readily from virus-infected tissues; nevertheless, BPEV dsRNA yields were consistently higher than dsRNA yields of CmEV. The dsRNA of both viruses was affected similarly by the amylase, pepsin, and $\mathrm{pH}$ treatments. Incubating tissue macerates or $\mathrm{pu}-$ rified dsRNA at $37^{\circ} \mathrm{C}$ for $2 \mathrm{~h}$ did not affect successful extraction of dsRNAs. The loss of the dsRNA structural integrity appeared to be more effective when purified dsRNA was treated than treatment of dsRNA-containing tissue macerates. This could be due to a less-efficient effect of the treatment when plant materials are present. The results of the combined treatments on tissue macerates were similar to those obtained with single treatments (Fig. S1). Amylase, an enzyme that catalyzes the hydrolysis of starch into sugars, is involved in one of the initial steps of digestion (Del Vigna de et al. 2008). In our investigations, the three concentrations of amylase used did not affect the integrity of the dsRNA of BPEV or CmEV (Fig. S2). Although, a slight effect is evident in Fig. S2, we think that this may be due to the presence of the enzyme in the electrophoresed samples. In contrast, the three concentrations of pepsin affected the integrity of the dsRNA of both endornaviruses when applied to both tissue macerates and purified dsRNA. Gel electrophoresis analysis of dsRNA, derived from pepsin-treated tissue macerates from infected fruits, showed partial dsRNA degradation (Fig. 1). The results of treating the dsRNAs with three pepsin concentrations were similar which may be due to the narrow range of pepsin concentrations used in the experiments. When purified BPEV or

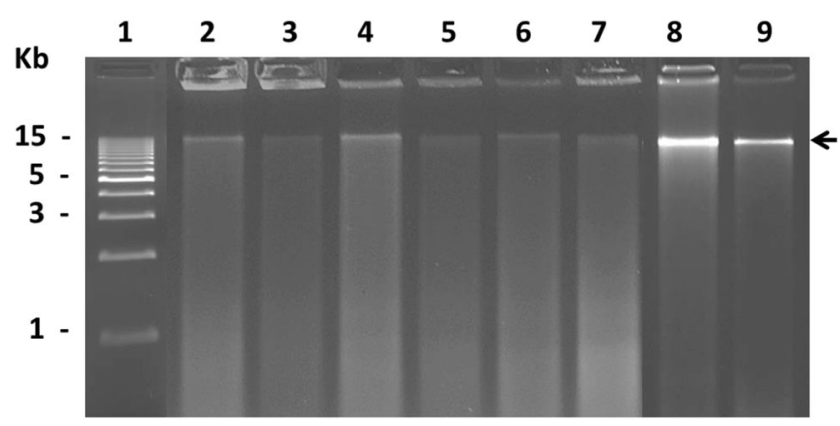

Fig. 1 Agarose gel electrophoresis of dsRNA extracted from bell pepper and melon fruit tissues infected with bell pepper endornavirus (BPEV) and Cucumis melo endornavirus $(\mathrm{CmEV})$, respectively. Before dsRNA extraction, tissues were macerated and incubated for $2 \mathrm{~h}$ at $37^{\circ} \mathrm{C}$ with 0.50 (lanes 2-3), 0.75 (lanes 4-5), and 1.0 (lanes 6-7) $\mathrm{mg} / \mathrm{mL}$ of pepsin. Lane 1, 1-kb marker; lanes 2, 4, 6, and 8, BPEV; lanes 3, 5, 7, and 9, CmEV. Lanes 8 and 9, buffer-treated dsRNA. DsRNA sample load consisted of $15 \mu \mathrm{L}$. Arrow indicates the relative position of dsRNAs

PMMoV dsRNA was treated with pepsin, in addition to partial degradation, an abnormal electrophoretic migration (slower migration) of the dsRNA was observed (Figs. S3 and S6). Purified dsRNA treated with $0.50 \mathrm{mg} / \mathrm{mL}$ of pepsin exhibited a slightly faster mobility when compared with dsRNA treated with 0.75 and $1.0 \mathrm{mg} / \mathrm{mL}$ (Figs. S3 and S6). The slower migration of pepsin-treated (all three pepsin concentrations) BPEV dsRNA may be due to a more relaxed or perhaps linearized form of the native (non-denatured) dsRNA molecules resulting from the treatment. Similar results were obtained when purified dsRNA of CmEV was treated (results not shown). RT-PCR testing of BPEV dsRNA samples derived from pepsin-treated tissue macerates was positive (Fig. S4). Similar results were obtained when CmEV dsRNA samples derived from pepsin-treated tissue macerates were tested by RT-PCR (results not shown). This suggests that although pepsin degraded some of the dsRNA, the RT-PCR target sequence was not affected and was available for amplification. In contrast, pepsin-treated purified BPEV dsRNA not only modified the normal electrophoretic migration of the dsRNA but also degraded the RT-PCR target sequence and, therefore, the virus was not detected (Fig. S4). These results suggest that pepsin applied to the tissue macerates is less efficient in degrading the dsRNA when compared with treatments of purified dsRNA. The effect of pepsin on the structural integrity of endornavirus dsRNA is not surprising. Recently, it has been shown that pepsin can degrade DNA (Liu et al. 2015). Degradation of DNA by pepsin is similar to endonucleases; pepsin prefers to cleave purine-rich sequences (Zhang et al. 2016).

RNA is susceptible to acid hydrolysis at $\mathrm{pH}<2$ (Bernhardt and Tate 2012). At extremely low or high $\mathrm{pH}$ values, the phosphodiester bond of RNA is disrupted, cleaving the RNA into nucleotides and nucleosides. Acidic buffer or gastric media from humans have been reported to rapidly inactivate the dsRNA of orally transmitted animal rotaviruses (Weiss and Clark 1985). These viruses were inactivated at $\mathrm{pH} 2.0$ but at a much slower 
rate at higher $\mathrm{pH}$. Similarly, in simulated human gastric media, CPMV was stable at $\mathrm{pH} \geq 2.5$ (Berardi et al. 2018). At lower $\mathrm{pH}$, destabilization of the particle structure occurred. By exposing dsRNA to $\mathrm{pH}$ values similar to those found in the human gastric media, we obtained similar results to those reported by Weiss and Clark (1985). The dsRNA integrity of BPEV and CmEV was not affected when samples were exposed to $\mathrm{pH} 3.0$ or 4.0 (Fig. 2). However, at $\mathrm{pH}$ 2.0, faint dsRNA bands were observed in gels loaded with purified dsRNA and both viruses were detected by RT-PCR (Fig. 2 and Fig. S4). At pH 1.0, the dsRNAs were not detected by gel electrophoresis or RT-PCR. Similar results were obtained when dsRNA extracts from tissue macerates of both endornaviruses were subjected to the various $\mathrm{pH}$ treatments. Overall, experiments with purified PMMoV dsRNA yielded similar results (Figs. S5-S7). The only difference was that at $\mathrm{pH} 2.0, \mathrm{PMMoV}$ was degraded and the RT-PCR target not detected (Figs. S5 and S7).

Our results show that under the simulated gastric conditions used in this investigation, the structural integrity of the RI dsRNA of BPEV and CmEV can be negatively affected. Electrophoresis and RT-PCR results of the $\mathrm{pH}$ treatments of endornavirus dsRNA support that depending upon the individual (human) $\mathrm{pH}$ value in their digestive system (which is affected by several factors including amount and type of food consumed), these dsRNAs are not degraded at $\mathrm{pH} 3$ or above or may be partially degraded at $\mathrm{pH} 2$. Pepsin treatments of dsRNA containing tissue showed limited dsRNA degradation. Therefore, when consuming these endornavirus-infected fruits, it is likely that our digestive organs are exposed to both fragmented and full-length RI dsRNA of BPEV and CmEV. The fate of these dsRNAs in the lower digestive system is not known. Nevertheless, it has been shown that infectious PMMoV can be recovered from human feces after consumption of virusinfected peppers (Colson et al. 2010; Zhang et al. 2006). It is

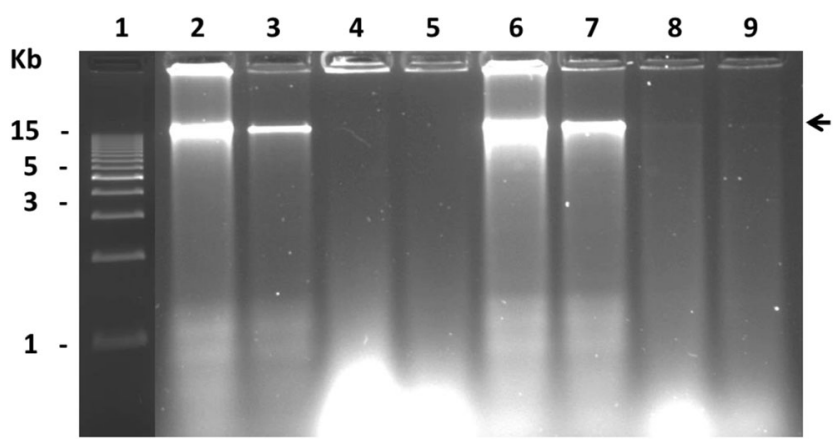

Fig. 2 Agarose gel electrophoresis of dsRNA extracted from bell pepper and melon fruit tissues infected with bell pepper endornavirus (BPEV) and Cucumis melo endornavirus $(\mathrm{CmEV})$, respectively. Before dsRNA extraction, tissues were macerated and incubated for $2 \mathrm{~h}$ at $37^{\circ} \mathrm{C}$ at different $\mathrm{pH}$ values. Lane 1, 1-kb marker; lane 2, BPEV pH 3.0; lane 3, $\mathrm{CmEV}$ pH 3.0; lane 4, BPEV pH 1.0; lane 5, CmEV pH 1.0; lane 6, BPEV pH 4.0; lane 7, CmEV pH 4.0; lane 8, BPEV pH 2.0; and lane 9, $\mathrm{CmEV}$ pH 2.0. DsRNA sample load consisted of $25 \mu \mathrm{L}$. Arrow indicates the relative position of dsRNAs possible that virus-infected tissues were not completely degraded during digestion and intact virions recovered form feces.

Oryza sativa endornavirus (OsEV) has been reported in some rice cultivars (Fukuhara et al. 1993). Kasumba et al. (2017) used the dsRNA of this virus to stimulate the immune response in mice and obtained a strong immune reaction. Moreover, the OsEV dsRNA treatment in mice suppressed replication of Influenza A virus at an early stages of infection. In another study using BPEV, Hajake et al. (2019) reported melanoma-suppressive effects in mice after injecting them with BPEV dsRNA. Furthermore, they found that BPEV dsRNA acted as an effective vaccine adjuvant. These reports illustrate potential practical applications of endornaviral dsRNAs.

It is not known if these dsRNAs have any effects in humans, although it has been shown that exogenous plant micro-RNAs acquired orally through food intake can regulate the expression of target genes in mammals (Zhang et al. 2012). The results of this investigation may be extrapolated to the replicative intermediate and genomic dsRNAs of viruses present in other plants and plant-derived food products.

Acknowledgments The authors would like to thank C.S. Kousik, USDA Vegetable Laboratory, Charleston, SC, and M.J. Roossinck, Penn State University, State College, PA, for providing endornavirus-infected cucurbit and pepper seeds, respectively. We also wish to thank Andrea Hebert, Middleton Library, Louisiana State University, for proof reading the manuscript and the Episcopal High School, Baton Rouge ESTAAR program for sponsoring the internship of Adair McCanless and Allison Hultgren.

Funding information Partial support for this investigation was provided by the National Institute of Food and Agriculture, USDA.

\section{Compliance with ethical standards}

Conflict of interest The authors declare that they have no conflict of interest.

Ethical approval This article does not contain any studies with human participants or animals performed by any of the authors.

Informed consent Informed consent was obtained from all individual participants included in the study.

Open Access This article is distributed under the terms of the Creative Commons Attribution 4.0 International License (http:// creativecommons.org/licenses/by/4.0/), which permits unrestricted use, distribution, and reproduction in any medium, provided you give appropriate credit to the original author(s) and the source, provide a link to the Creative Commons license, and indicate if changes were made.

\section{References}

Berardi A, Evans DJ, Bombellic FB, Lomonossoff GP (2018) Stability of plant virus-based nanocarriers in gastrointestinal fluids. Nanoscale 10:1667-1679

Bernhardt HS, Tate WP (2012) Primordial soup or vinaigrette: did the RNA world evolve at acidic pH? Biol Direct 7:4 http://www. biology-direct.com/content/7/1/4 
Boccardo G, Lisa V, Luisini E, Milne RG (1987) Cryptic plant viruses. Adv Virus Res 32:171-214

Colson P, Richet H, Desnues C, Balique F, Moal M, Grob J-J, Berbis P, Lecoq H, Harlé JR, Berland Y, Raoult D (2010) Pepper mild mottle virus, a plant virus associated with specific immune responses, fever, abdominal pains, and pruritus in humans. PLoS ONE 5(4):e10041. https://doi.org/10.1371/journal.pone.0010041

da Costa AC, Leal E, Gill D et al (2019) Discovery of Cucumis melo endornavirus by deep sequencing of human stool samples in Brazil. Virus Genes 55:332-338. https://doi.org/10.1007/s11262-01901648-0

Del Vigna de Almeida P, Tridade Gregio AM, Naval Machado MA, Soares de Lima AA, Reis Azevedo L (2008) Saliva composition and functions: a comprehensive review. J Contemp Dent Pract 9: $1-11$

Escalante C, Alcalá-Briseño RI, Valverde RA (2018) Pepper mild mottle virus and tobacco mild green mosaic virus in pepper (Capsicum апnиum) in the United States. Plant Dis 102:1469

Foltz E, Azad S, Everett EL et al (2015) An assessment of human gastric fluid composition as a function of PPI usage. Physiol Rep 3(1): e12269. https://doi.org/10.14814/phy2.12269

Fukuhara T (2019) Endornaviruses: persistent dsRNA viruses with symbiotic properties in diverse eukaryotes. Virus Genes 55:165-173. https://doi.org/10.1007/s11262-019-01635-5

Fukuhara T, Moriyama H, Pak JK, Hyakutake T, Nitta T (1993) Enigmatic double-stranded RNA in Japonica rice. Plant Mol Biol 21:1121-1130

Hajake T, Matsuno K, Kasumba DM, Oda H et al (2019) Broad and systemic immune-modulating capacity of plant-derived dsRNA. Jpn Soc Immunol. https://doi.org/10.1093/intimm/dxz054/5542381

Jarret RL, Gillaspie AG, Barkley NA, Pinnow DL (2008) The occurrence and control of pepper mild mottle virus (PMMoV) in the USDA/ ARS Capsicum germplasm collection. Seed Technol 30:26-36

Kalipatnapu P, Kelly RH, Rao KN, Thiel DH (1983) Salivary composition: effects of age and sex. Acta Medica Port 4:327-330

Kasumba DM, Hajake T, Oh S-W, Kotenko SV, Kato H, Fujita T (2017) A plant-derived nucleic acid reconciles type I IFN and a pyroptoticlike event in immunity against respiratory viruses. J Immunol. https://doi.org/10.4049/jimmunol.1700523

Khankhum S, Escalante C, Rodrigues de Souto E, Valverde RA (2017) Extraction and electrophoretic analysis of large dsRNAs from desiccated plant tissues infected with plant viruses and biotrophic fungi. Eur J Plant Pathol 147:431-441

Liu Y, Zhang Y, Dong P, An R, Xue C, Ge Y, Wei L, Liang X (2015) Digestion of nucleic acids starts in the stomach. Sci Rep 5:11936. https://doi.org/10.1038/srep11936

Lu P-J, Hsu P-I, Chen C-H et al (2010) Gastric juice acidity in upper gastrointestinal diseases. World J Gastroenterol 16:5496-5501. https://doi.org/10.3748/wjg.v16.i43.5496

Mandel AL, Des Gachons CP, Plank KL, Alarcon S, Breslin PAS (2010) Individual differences in AMY1 gene copy number, salivary $\alpha$ amylase levels, and the perception of oral starch. PLoS ONE 5(10):e13352. https://doi.org/10.1371/journal.pone.0013352
Okada R, Kiyota E, Sabanadzovic S, Moriyama H, Fukuhara T, Saha P, Roossinck MJ, Severin A, Valverde RA (2011) Bell pepper endornavirus: molecular and biological properties and occurrence in the genus Capsicum. J Gen Virol 92:2664-2673

Pavan MA, Krause-Sakate R, Silva ND, Zerbini FM, Le Gall O (2008) Virus diseases of lettuce in Brazil. Plant Viruses 2:35-41

Roberts NB, Sheers R, Taylor WH (2007) Secretion of total pepsin and pepsin 1 in healthy volunteers in response to pentagastrin and to insulin-induced hypoglycaemia. Scand J Gastroenterol 42:555-561

Roossinck MJ (2010) Lifestyles of plant viruses. Philos Trans R Soc Lond B Biol Sci 365:1899-1905

Sabanadzovic S, Wintermantel WM, Valverde RA, McCreight JD, Aboughanem-Sabanadzovic N (2016) Cucumis melo endornavirus: genome organization, host range and co-divergence with the host. Virus Res 214:49-58

Szostek SA, Rodriguez P, Sanchez J, Adkins S, Naidu RA (2017) Westen flower thrips can transmit Tomato spotted wilt virus from virusinfected tomato fruits. Plant Health Prog 18:1-6. https://doi.org/10. 1094/PHP-RS-16-0057

Valverde RA, Khalifa ME, Okada R, Fukuhara T, Sabanadzovic S (2019) ICTV virus taxonomy profile: Endornaviridae. J Gen Virol. https:// doi.org/10.1099/jgv.0.001277

Valverde RA, Sabanadzovic S, Rush MC (2011) Identification of Oryza sativa endornavirus in rice genotypes from breeding programmes in the United States. Plant Breed 130:271-274

Wakarchuk DA, Hamilton RI (1985) Cellular double-stranded RNA in Phaseolus vulgaris. Plant Mol Biol 5:55-63

Weiss C, Clark HF (1985) Rapid inactivation of rotaviruses by exposure to acidic buffer or acidic gastric juice. J Gen Virol 66:2725-2730

Zabalgogeazcoa IA, Gildow FE (1992) Double-stranded ribonucleic acid in 'Barsoy' barley. Plant Sci 83:187-194

Willenborg J, Menzel W, Vetten HJ, Maiss E (2009) Molecular characterization of two alphacryptovirus dsRNAs isolated from Daucus carota. Arch Virol 154:541-543

Zhang T, Breitbart M, Lee WH et al (2006) RNA viral community in human feces: prevalence of plant pathogenic viruses. PLoS Biol. 4(1):e3. https://doi.org/10.1371/journal.pbio.0040003

Zhang L, Hou D, Chen X et al (2012) Exogenous plant MIR168a specifically targets mammalian LDLRAP1: evidence of cross-kingdom regulation by microRNA. Cell Res 22:107-126. https://doi.org/10. 1038/cr.2011.158

Zhang Y, Li C, Liu Y, Wang X, Dong P, Liang X (2016) Mechanism of extraordinary DNA digestion by pepsin. Biochem Biophys Res Commun 472:101-107

Zhu H, Hart CA, Sales D, Roberts NB (2006) Bacterial killing in gastric juice - effect of $\mathrm{pH}$ and pepsin on Escherichia coli and Helicobacter pylori. J Med Microbiol 55:1265-1270

Publisher's note Springer Nature remains neutral with regard to jurisdictional claims in published maps and institutional affiliations. 